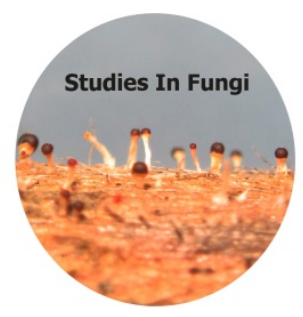

Studies in Fungi 4(1): 205-215 (2019) www.studiesinfungi.org ISSN 2465-4973

\title{
Article
}

Doi 10.5943/sif/4/1/22

\section{An updated checklist of macrofungi of Vivara island (gulf of Naples - Italy)}

\author{
Lubrano Lavadera $A^{1^{*}}$, Mazzella $\mathrm{V}^{2 *}$ and $\mathrm{D}^{\text {'Antonio }} \mathrm{C}^{3}$ \\ ${ }^{1}$ Via Liberta' 22, 80079 Procida (NA) \\ ${ }^{2}$ Stazione Zoologica Anton Dohrn Villa Comunale 80121 Napoli \\ ${ }^{3}$ LIPU Via M. Chiaiolella, 5880079 Procida \\ *The authors contributed equally to this work
}

Lubrano Lavadera A, Mazzella V, D’Antonio C 2019 - An updated checklist of macrofungi of Vivara island (gulf of Naples - Italy). Studies in Fungi 4(1), 205-215, Doi 10.5943/sif/4/1/22

\begin{abstract}
Islands are special environments for studying fungi. On the Vivara island, an integral natural reserve, several taxonomic studies have been performed in the last decades but the taxonomic composition of the mycoflora is still not clear. For this reason, here we present an updated checklist of the mycoflora present on the island, part of a more complex work that allowed the mapping of all the living species present in this precious natural park, over the past decade.
\end{abstract}

Key words - Ascomycota - Basidiomycota - Fungi - Natural reserve - Taxonomy

\section{Introduction}

Vivara island (Fig. 1) (4044'73" N, 1359'69"E) is situated in the Gulf of Naples between the islands of Ischia and Procida. Since 1957 a pedestrian bridge, about 200 meters long, has connected Procida to Vivara. On 2002, Vivara became State Nature Reserve, and it was classified as a Site of Community Importance (SIC) according to the Directive no. 92/43/EEC and as a Special Protection Area (ZPS) for migratory birds according to the Directive no 79/409/EEC. Currently, the access to Vivara is limited to authorized people and is totally protected.

The island has a surface of 32 hectares reaching a maximum altitude of approximately $109 \mathrm{~m}$ above sea level. Vivara represents the well-preserved west side of a volcanic crater, which arose between 75000 and 40000 years ago (De Astis et al. 2004, Aiello et al. 2007). The emerged part of the crater consists of lithified hydro-magmatic tuffs with a yellowish ashy matrix in which abundant dark-grey, larger pyroclasts are dispersed (De Astis et al., l.c.). Above these rocks lie different pyroclastic deposits (mainly pumices and tuffs) originating from the nearby volcanoes (Procida, Ischia and Campi Flegrei), with interposed palaeosols (De Astis et al., l.c.).

Until the beginning of the 19th Century, the dominant vegetation on Vivara consisted of Quercus ilex L. forests; these were largely replaced in 1833 by olive-trees (Olea europaea L.), which were cultivated until the beginning of the 1970s (Scotto di Cesare 2009). In the last decades, spontaneous vegetation recolonized the abandoned olive plantations, now the olive trees have an oleaster-like appearance due to lack of pruning and of removal of the undergrowth.

Relic woodlands are still present particularly along path margins, where they were preserved due to their importance as windbreaks, as testified by the presence of big, old oaks (mainly Quercus pubescens Willd., with some $Q$. ilex) along the eastern and western slopes, more exposed to the 
wind. Caputo (1964) regarded Q. pubescens as autochthonous and characteristic for a mesophilous aspect of the vegetational association Quercetum ilicis, quite rare on small mediterranean islands.

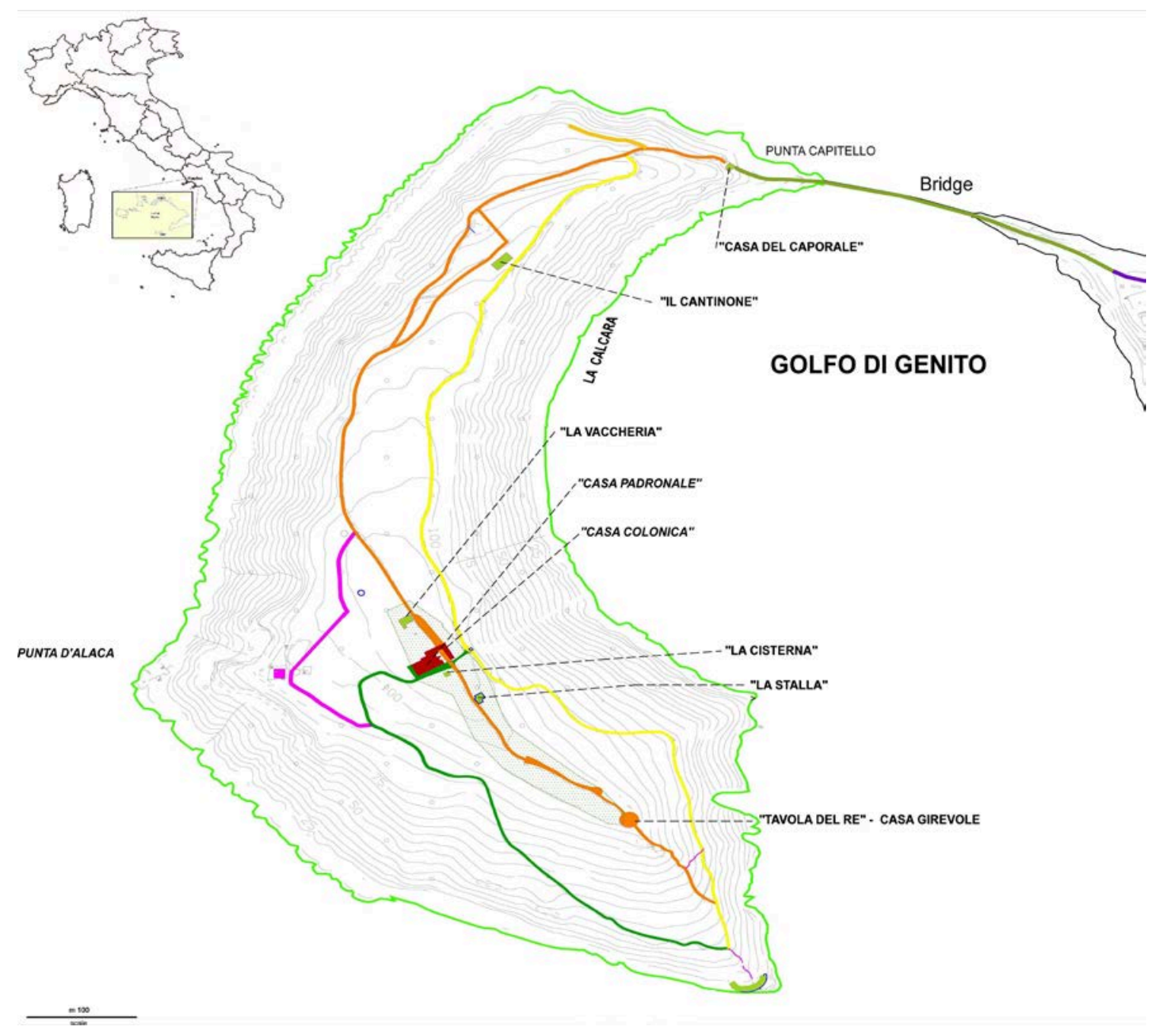

Fig. 1 - A detailed map of Vivara island

About 20 years ago, Violante et al. (1999) published a paper focused on the mycoflora of Vivara island. We found many differences concerning the vegetation and the places where the mushrooms were found, for example "under the birches" or "at the limits of the cultivated fields"; since in Vivara nature reserve there are neither birch trees nor cultivated fields since 1970, we thought it appropriate to start from zero with this reviewed note of the island macromycetes. Moreover, we have found several errors in the taxonomic determination of the species considering that the authors of the previous paper were all botanists, but no one was mycologist. For instance, it is curious that no one has previously recorded the presence on the island of the fungus Omphalotus olearius: this species is bright yellow, bioluminescent, invasive, ad and mainly associated with Olea europea. We have found the fungus in all periods of the year, ad in our opinion it is quite impossible to miss it, considering the small extension of the island. Hydnum repandum has been confused with Hydnum rufescens. An incredible mistake has been committed with the taxonomic determination of Boletus edulis. It's clearly difficult to find this fungus at sea level, and in the Mediterranean scrub, while in our observations we have found several specimens of Boletus aereus, typical of the Mediterranean environment, and very abundant in this kind of habitat.

An important contribution to the knowledge of the mykoflora of our neighbouring region has been published by Roca et al. 2007. The mycobiota composition of the island is in agreement with the fungal composition of the Mediterranean habitat here reported, with some exceptions as 
Lactarius tesquorum, that is in a specific mycorrhizal association with Cistus spp. that is usually a rare mushroom because of the lack of habitat in our region, but it is easy to find on the islet of Vivara due to the presence of several square meters colonized by Cistus spp.. The presence on the islet of Clathrus ruber is very high compared to other nearby areas (Mazzella., pers. obs.). This species in fact likes stable habitats and it is indicative of a good and not polluted environments (Mazza, 2010).

\section{Materials \& Methods}

\section{Area specifications}

Vivara island has a Mediterranean climate, classifiable as "Csa” according to Köppen (1936), where "C" stays for a temperate climate in which the mean temperature of the coldest month is lower than $18^{\circ} \mathrm{C}$ but higher than $-3^{\circ} \mathrm{C}$, and in which at least one month has a mean temperature higher than $10^{\circ} \mathrm{C}$; "s" indicates the presence of a dry season in summer and "a" stays for a hot summer, with a mean temperature of the hottest month higher than $22^{\circ} \mathrm{C}$. The weather station nearest to Vivara is located on the high school on the nearby island of Procida; basing on the data recorded by this station in the years 2003-2009, on the islands exist the presence of a dry season between the first week of May and the beginning of September; precipitations are scarce (650 $\mathrm{mm}$ /year), but its relative humidity is higher than $70 \%$ the whole year round due to the vicinity of the sea. The maximum temperatures are lowest in February (mean: $6^{\circ} \mathrm{C}$ ) and highest in August (mean: $31^{\circ} \mathrm{C}$ ).

The most common habitat on Vivara is the tall Mediterranean scrub, particularly widespread on the northwest and southeast facing slopes; here dominate Erica arborea L. and Arbutus unedo L., whereas Ceratonia siliqua L. is not uncommon. Erica arborea is particularly abundant on the southwestern slopes, where it forms almost monospecific assemblages associated with an impoverishment and acidification of the soil (Scotto di Cesare, 1999). The low Mediterranean scrub is dominated by Myrtus communis L., Pistacia lentiscus L. and Olea europaea var. oleaster Hoffmansegg \& Link; at some points, it is degraded into a garrigue, with increasing presence of Cistus monspeliensis L. and Euphorbia dendroides L. (Scotto di Cesare, l. c.). In the last decades, the low Mediterranean scrub has become restricted to the steepest slopes, and the garrigue has lost most surface. The natural vegetational succession led to a rarefaction of open grasslands, which may be the cause for the observed concentration of grazing by wild rabbits on the summit plateau (Santangelo et al., 2014).

Faunistic research on birds, with more than 120 species recorded, was conducted on Vivara between 1975 and 1990 and again since 2010 thanks to a new ringing station promoted and operated by the Italian League for Bird Protection (LIPU); most recorded species are migratory birds, which are present only in the winter or visit the island for reproduction in spring and summer; 15 species are resident on Vivara (Cavaliere et al., 2012).

The island also hosts four species of Reptiles (Hierophis viridiflavus (Lacépède), Podarcis sicula (Rafinesque), Tarentola mauritanica (L.) and Hemidactylus turcicus (L.)), and 11 species of mammals (Pipistrellus kuhlii, Tadarida teniotis, Pipistrellus pipistrellus, Hypsugo savii, Myotis myotis/blythii, Eptesicus serotinus, Mniopterus shreibersi, Myotis sp. (Lancillotto 2014), Oryctolagus cuniculus (L.), Rattus norvegicus (Berkenhout), Rattus rattus (L.), Apodemus sylvaticus (L.) and Mus musculus L.) (Nappi et al., 2007)).

The following checklist of macromycetes species was compiled through our direct observations, during the 2015-2017 three-years period. During these years we performed in total ca. 20 specific visits for the fungal identifications. In our region, the fall season (October, November and December) is the best period to study fungi, due to the low amount of precipitations. In these three months, we performed a collecting session every 2 weeks every time covering all the habitats of the island (3 principal areas). During the other months of the year, we performed 6 sessions in total, because it's quite difficult to find fungi outside the fall window according to the climate specifics. All the specimens were analyzed on field, collected and taken to the laboratory for the 
microscope analysis. For every species, a sample has been dried and preserved for the exsiccata collection. Moreover, for every recorded species, a sample of the spores has been collected and stored at $4^{\circ} \mathrm{C}$. A sample of every record has been dried and stored in our private collection.

For the taxonomic determination, we used the keys to identification provided by the following publications: Consiglio \& Papetti, 2001, id., 2009,. Consiglio et al., 2001, Courtecuisse \& Duhem, 2013. We also followed "Index Fungorum" as a nomenclatural database in order to avoid wrong names and to be sure of the last nomenclature of all the specimens. Moreover, we confirmed the trophy of our species following Consiglio \& Papetti, 2001, id., 2009 and Consiglio et al., 2001.

\section{Results}

Our updated fungal species checklist is composed of over 40 species (Table 1); 22 of them are new records for the island. All the species reported in this article have been previously recorded in the neighboring regions and in Italy too. An example of the most representative species is reported in Fig. 3.

\section{Discussion}

Fungi have several trophic strategies; according to the species, we can find the symbiotic strategy (mycorrhizal), the parasitic strategy and the saprotrophic one. The trophic strategy of the species is reported in the table 1 . We can see in fig. 2 that $50 \%$ of the species are saprotrophic species, $42 \%$ are mycorrhizal and the remaining species are mostly parasitic. Most of the species are parasitic species, probably because the vegetation on the island is still changing: it hasn't been cultivated since almost 50 years. Nowadays the vegetation is becoming richer and richer in climactic species as Quercus spp., thus we expect that in the next 30 years a climatic stage of the vegetation will be reached and the fungal composition could change, and move to a richer mycorrhizal composition in species.

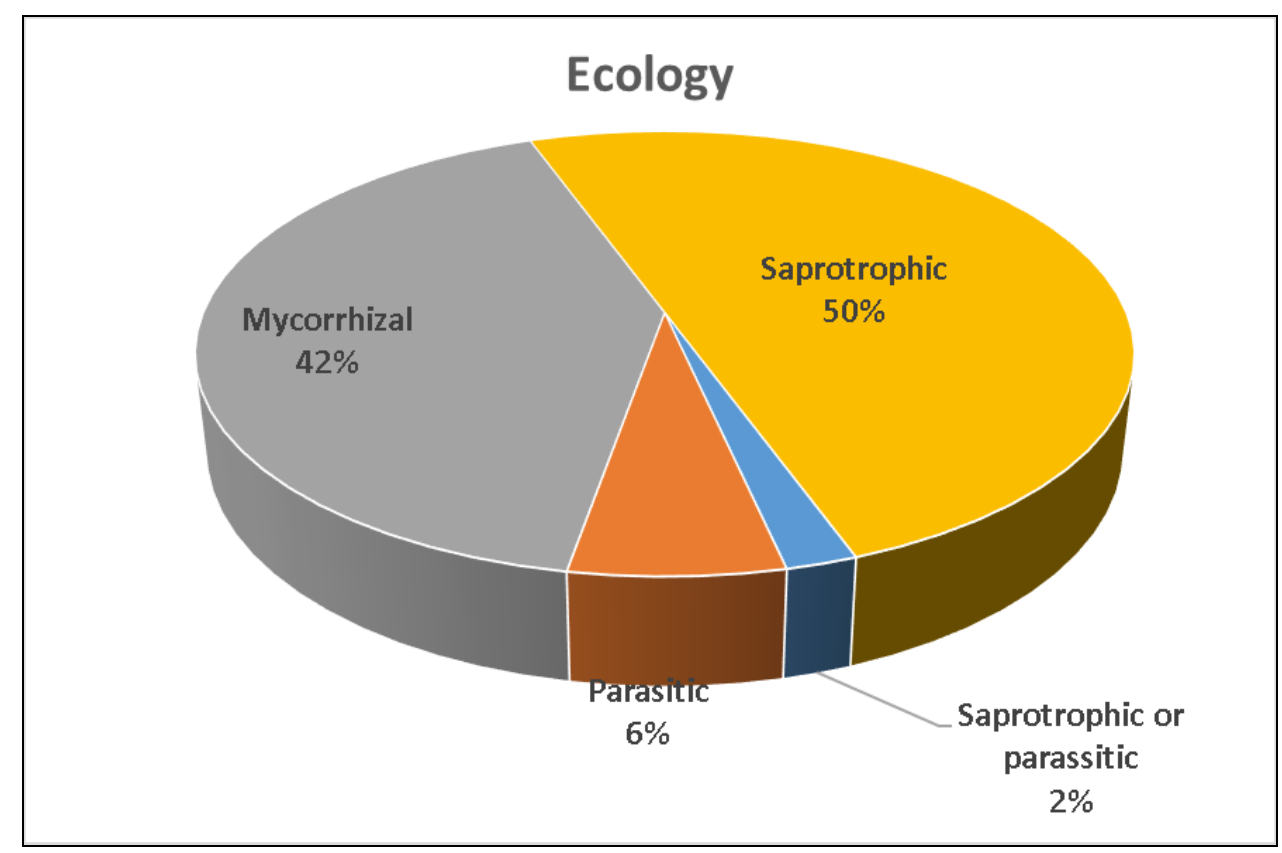

Fig. 2 - Graphical distribution of the species based on the trophic behaviour.

Table 2 reports for each taxon the numbers of collected specimens and the name of the collector. The number of records regards the official sampling sessions. The most abundant species are $A$. mellea and $O$. olearius reaching a high number of specimens due to their trophy strategy (wood growing fungi) and their biology (caespitosus fungi). 
The genus Amanita is very well represented with a peak of specimens regarding A. pantherina, one of the most common mushrooms on the island. L. gentianeus is very common at the end of autumn, when the temperature is lower than usual. C. ruber it is usually a quite rare mushroom, biological indicator of a stable environment, here very common. For genus Tricholoma we have only collected just one specimen.

The Xerocomus genus is largely represented on the island, but since it is a taxonomic complex that is still unclear, we did not go into the specific classification, waiting for a better revision of the genus. There are still many lacks in censing all the macrofungi species of the island, in fact the genera Lepiota, Russula, Xerocomus, and Agaricus are very abundant in number of specimen recorded but for all these Genera a visual taxonomic determination is not sufficient and some more molecular analyses will be performed.

The fungal composition of the island of Vivara is not completed, it is still under investigation and our idea is to produce a more complex work considering the possibility of identifying all species through molecular analysis, in order to complete our census project of all species of macrofungi in the islands of the Gulf of Naples.

Table 1 The fungal species checklist of Vivara island

\begin{tabular}{|c|c|c|c|c|c|}
\hline Class & Order & Family & Genus & Species & Ecology \\
\hline \multirow{15}{*}{$\begin{array}{l}\text { AGARICOMYCET } \\
\text { ES }\end{array}$} & AURICULARIALES & AURICULARIACEAE & Auricularia & Auricularia auricula-judae (Bull.) Quél. & Saprotrophic \\
\hline & \multirow{14}{*}{ AGARICALES } & \multirow{7}{*}{ AGARICACEAE } & \multirow{2}{*}{ Agaricus } & Agaricus bisporus (J.E. Lange) Imbach & Saprotrophic \\
\hline & & & & Agaricus porphyrizon P.D. Orton & Saprotrophic \\
\hline & & & Bovistella & $\begin{array}{c}\text { Bovistella utriformis (Bull.) Demoulin \& } \\
\text { Rebriev }\end{array}$ & Saprotrophic \\
\hline & & & \multirow{3}{*}{ Macrolepiota } & Macrolepiota mastoidea (Fr.: Fr.) Sing. & Saprotrophic \\
\hline & & & & Macrolepiota procera (Scop.: Fr.) Singer & Saprotrophic \\
\hline & & & & Macrolepiota sp. & Saprotrophic \\
\hline & & & Lepiota & Lepiota spp. & Saprotrophic \\
\hline & & \multirow{7}{*}{ AMANITACEAE } & \multirow{7}{*}{ Amanita } & Amanita crocea (Quél.) Singer & Mycorrhizal \\
\hline & & & & Amanita gemmata (Fr.) Bertill. 1866 & Mycorrhizal \\
\hline & & & & Amanita pantherina (DC.) Krombh & Mycorrhizal \\
\hline & & & & $\begin{array}{c}\text { Amanita phalloides (Vaill. ex Fr.: Fr.)Link } \\
1833\end{array}$ & Mycorrhizal \\
\hline & & & & Amanita subnudipes (Romagn.) Tulloss & Mycorrhizal \\
\hline & & & & Amanita sp. & Mycorrhizal \\
\hline & & & & Amanita verna (Bull.: Fr.) Lam. 1783 & Mycorrhizal \\
\hline
\end{tabular}


Table 1 Continued.

\begin{tabular}{|c|c|c|c|c|c|}
\hline Class & Order & Family & Genus & Species & Ecology \\
\hline & & \multirow{2}{*}{$\begin{array}{c}\text { HYMENOGASTRACEA } \\
\text { E }\end{array}$} & Gymopilus & Gymnopilus sp. & Saprotrophic \\
\hline & & & Galerina & Galerina marginata (Batsch) Kühner & Saprotrophic \\
\hline & & HYGROPHORACEAE & Hygrocybe & Hygrocybe acutoconica (Clem.) Singer & Mycorrhizal \\
\hline & & INOCYBACEAE & Inocybe & $\begin{array}{c}\text { Inocybe geophylla var. Lilacina (Peck) } \\
\text { Gillet }\end{array}$ & Mycorrhizal \\
\hline & & OMPHALOTACEAE & Omphalotus & Omphalotus olearius (DC.) Singer & Saprotrophic \\
\hline & & \multirow{4}{*}{ TRICHOLOMATACEAE } & Clitocybe & Clitocybe gibba (Pers.) P. Kumm. & Saprotrophic \\
\hline & & & Infundibulicybe & Infundibulicybe geotropa (Bull.) Harmaja & Saprotrophic \\
\hline & & & Lepista & Lepista panaeolus (Fr.) P. Karst. & Saprotrophic \\
\hline & & & Leucopaxillus & Leucopaxillus gentianeus (Quél.) Kotl & Mycorrhizal \\
\hline \multirow{14}{*}{$\begin{array}{c}\text { AGARICOMYCET } \\
\text { ES }\end{array}$} & \multirow{5}{*}{ AGARICALES } & \multirow{2}{*}{ TRICHOLOMATACEAE } & Tricholoma & Tricholoma sp. & Saprotrophic \\
\hline & & & Tricholomopsis & Tricholomopsis rutilans (Schaeff.) Singer & Saprotrophic \\
\hline & & PHYSALACRIACEAE & Armillaria & Armillaria mellea (Vahl) P. Kumm. & Parasitic \\
\hline & & PSATHYRELLACEAE & Coprinus & Coprinus sp. & Parasitic \\
\hline & & PLEUROTACEAE & Pleurotus & Pleurotus eryngii var. ferulae (DC.) Quél. & Saprotrophic \\
\hline & & & Boletus & Boletus aereus Bull., Herb. Fr. & Mycorrhizal \\
\hline & & & Gyroporus & Gyroporus castaneus (Bull.) Quél. & Mycorrhizal \\
\hline & BOLETALES & BOLETACEAE & Suillellus & $\begin{array}{l}\text { Suillellus queletii (Schulzer) Vizzini, } \\
\text { Simonini \& Gelardi }\end{array}$ & Mycorrhizal \\
\hline & & & & Suillellus Iuridus (Schaeff.) Murrill & Mycorrhizal \\
\hline & & & Suillus & Suillus collinitus (Fr.) Kuntze & Mycorrhizal \\
\hline & & & Xerocomus & Xerocomus spp. & Mycorrhizal \\
\hline & $\begin{array}{l}\text { CHANTARELLALE } \\
\mathrm{S} \\
\end{array}$ & HYDNACEAE & Hydnum & Hydnum rufescens Pers. & Saprotrophic \\
\hline & DUAT I A CC & CLATHRACEAE & Clathrus & Clathrus ruber P. Micheli ex Pers. & Saprotrophic \\
\hline & PHALLALES & PHALLACEAE & Phallus & Phallus impudicus L. & Saprotrophic \\
\hline
\end{tabular}


Table 1 Continued.

\begin{tabular}{|c|c|c|c|c|c|}
\hline Class & Order & Family & Genus & Species & Ecology \\
\hline & POLYPORALES & GANODERMATACEAE & Ganoderma & Ganoderma lucidum (Curtis) P. Karst. & $\begin{array}{c}\text { Saprotrophic or } \\
\text { Parasitic }\end{array}$ \\
\hline & \multirow{5}{*}{ RUSSULALES } & \multirow{5}{*}{ RUSSULACEAE } & \multirow{2}{*}{ Lactarius } & Lactarius chrysorrheus Fr. & Saprotrophic \\
\hline & & & & Lactarius tesquorum Malençon & Saprotrophic \\
\hline & & & \multirow{3}{*}{ Russula } & Russula amoenicolor Romagn. & Mycorrhizal \\
\hline & & & & Russula chloroides (Krombh.) Bres. & Mycorrhizal \\
\hline & & & & Russula delica Fr. & Mycorrhizal \\
\hline & $\begin{array}{c}\text { SCLERODERMAT } \\
\text { ALES }\end{array}$ & $\begin{array}{c}\text { SCLERODERMATACE } \\
\text { AE }\end{array}$ & Scleroderma & Scleroderma citrinum Pers. & Mycorrhizal \\
\hline MYXOGASTRIA & STEMONITIDA & STEMONITIDACEAE & Stemonitis & Stemonitis sp. & Saprotrophic \\
\hline PEZIZOMYCETES & PEZIZALES & HELVELLACEAE & Helvella & Helvella lacunosa Afzel. & Saprotrophic \\
\hline
\end{tabular}

Table 2 Individual collections data.

\begin{tabular}{|c|c|c|c|}
\hline Taxa & Trophia & $\begin{array}{l}\text { Number of } \\
\text { specimens }\end{array}$ & Collectors \\
\hline Auricularia auricula-judae (Bull.) Quél. & $\mathrm{S}$ & 10 & D’Antonio \\
\hline Agaricus bisporus (J.E. Lange) Imbach & $\mathrm{S}$ & 1 & Mazzella \\
\hline Agaricus porphyrizon P.D. Orton & $\mathrm{S}$ & 3 & Mazzella \\
\hline Bovistella utriformis (Bull.) Demoulin \& Rebriev & $\mathrm{S}$ & 13 & Lubrano \\
\hline Macrolepiota mastoidea (Fr.: Fr.) Sing. & $\mathrm{S}$ & 12 & Lubrano \\
\hline Macrolepiota procera(Scop.: Fr.) Singer & $\mathrm{S}$ & 17 & Lubrano \\
\hline Macrolepiota sp. & $\mathrm{S}$ & 31 & Lubrano \\
\hline Lepiota spp. & $\mathrm{S}$ & 15 & Mazzella \\
\hline Amanita crocea (Quél.) Singer & $\mathrm{M}$ & 9 & Mazzella \\
\hline Amanita gemmata (Fr.) Bertill. 1866 & $\mathrm{M}$ & 2 & Mazzella \\
\hline
\end{tabular}


Table 2 Continued.

\begin{tabular}{|c|c|c|c|}
\hline Taxa & Trophia & $\begin{array}{l}\text { Number of } \\
\text { specimens }\end{array}$ & Collectors \\
\hline Amanita pantherina (DC.) Krombh & $\mathrm{M}$ & 27 & D’Antonio \\
\hline Amanita phalloides (Vaill. ex Fr.: Fr.) Link 1833 & M & 3 & Mazzella \\
\hline Amanita subnudipes (Romagn.) Tulloss & M & 5 & Mazzella \\
\hline Amanita sp. & M & 20 & Lubrano \\
\hline Amanita verna (Bull.: Fr.) Lam. 1783 & $\mathrm{M}$ & 4 & D’Antonio \\
\hline Gymnopilus sp. & $\mathrm{S}$ & 16 & D'Antonio \\
\hline Galerina marginata (Batsch) Kühner & $\mathrm{S}$ & 7 & D’Antonio \\
\hline Hygrocybe acutoconica (Clem.) Singer & $\mathrm{M}$ & 37 & Mazzella \\
\hline Inocybe geophylla var. lilacina (Peck) Gillet & $\mathrm{M}$ & 1 & Mazzella \\
\hline Omphalotus olearius (DC.) Singer & $\mathrm{S}$ & $>50$ & D’Antonio \\
\hline Clitocybe gibba (Pers.) P. Kumm. & $\mathrm{S}$ & 2 & Mazzella \\
\hline Infundibulicybe geotropa (Bull.) Harmaja & $\mathrm{S}$ & 2 & D’Antonio \\
\hline Lepista panaeolus (Fr.) P. Karst. & $\mathrm{S}$ & 6 & Lubrano \\
\hline Leucopaxillus gentianeus (Quél.) Kotl & $\mathrm{M}$ & 35 & Lubrano \\
\hline Tricholoma sp. & $\mathrm{S}$ & 1 & D’Antonio \\
\hline Tricholomopsis rutilans (Schaeff.) Singer & $\mathrm{S}$ & 8 & D’Antonio \\
\hline Armillaria mellea (Vahl) P. Kumm. & $\mathrm{P}$ & $>50$ & D’Antonio \\
\hline Coprinus sp. & $\mathrm{P}$ & 11 & D’Antonio \\
\hline Pleurotus eryngii var. ferulae (DC.) Quél. & $\mathrm{S}$ & 14 & D’Antonio \\
\hline Boletus aereus Bull., Herb. Fr. & M & 20 & Lubrano \\
\hline Gyroporus castaneus (Bull.) Quél. & M & 3 & Mazzella \\
\hline Suillellus queletii (Schulzer) Vizzini, Simonini \& Gelardi & $\mathrm{M}$ & 1 & Mazzella \\
\hline Suillellus luridus (Schaeff.) Murrill & $\mathrm{M}$ & 4 & Lubrano \\
\hline
\end{tabular}


Table 2 Continued.

\begin{tabular}{|l|c|c|c|}
\hline \multicolumn{1}{|c|}{ Taxa } & Trophia & $\begin{array}{c}\text { Number of } \\
\text { specimens }\end{array}$ & Collectors \\
\hline Suillus collinitus (Fr.) Kuntze & $\mathrm{M}$ & 3 & D'Antonio \\
\hline Xerocomus spp. & $\mathrm{M}$ & $>40$ & D'Antonio \\
\hline Hydnum rufescens Pers. & $\mathrm{S}$ & 20 & Lubrano \\
\hline Clathrus ruber P. Micheli ex Pers. & $\mathrm{S}$ & 40 & D'Antonio \\
\hline Phallus impudicus L. & $\mathrm{S}$ & 10 & D'Antonio \\
\hline Ganoderma lucidum (Curtis) P. Karst. & $\mathrm{S}$ or P & 7 & D'Antonio \\
\hline Lactarius chrysorrheus Fr. & $\mathrm{S}$ & 2 & Mazzella \\
\hline Lactarius tesquorum Malençon & $\mathrm{S}$ & 9 & Mazzella \\
\hline Russula amoenicolor Romagn. & $\mathrm{M}$ & 13 & Lubrano \\
\hline Russula chloroides (Krombh.) Bres. & $\mathrm{M}$ & 2 & Mazzella \\
\hline Russula delica Fr. & $\mathrm{M}$ & 3 & Lubrano \\
\hline Scleroderma citrinum Pers. & $\mathrm{M}$ & 6 & D'Antonio \\
\hline Stemonitis sp. & $\mathrm{S}$ & 10 & Mazzella \\
\hline Helvella lacunosa Afzel. & $\mathrm{S}$ & 12 & D'Antonio \\
\hline Legenda: M=Mycorrhizal, P=Parasitic, S=Saprotrophic & & & \\
\hline
\end{tabular}



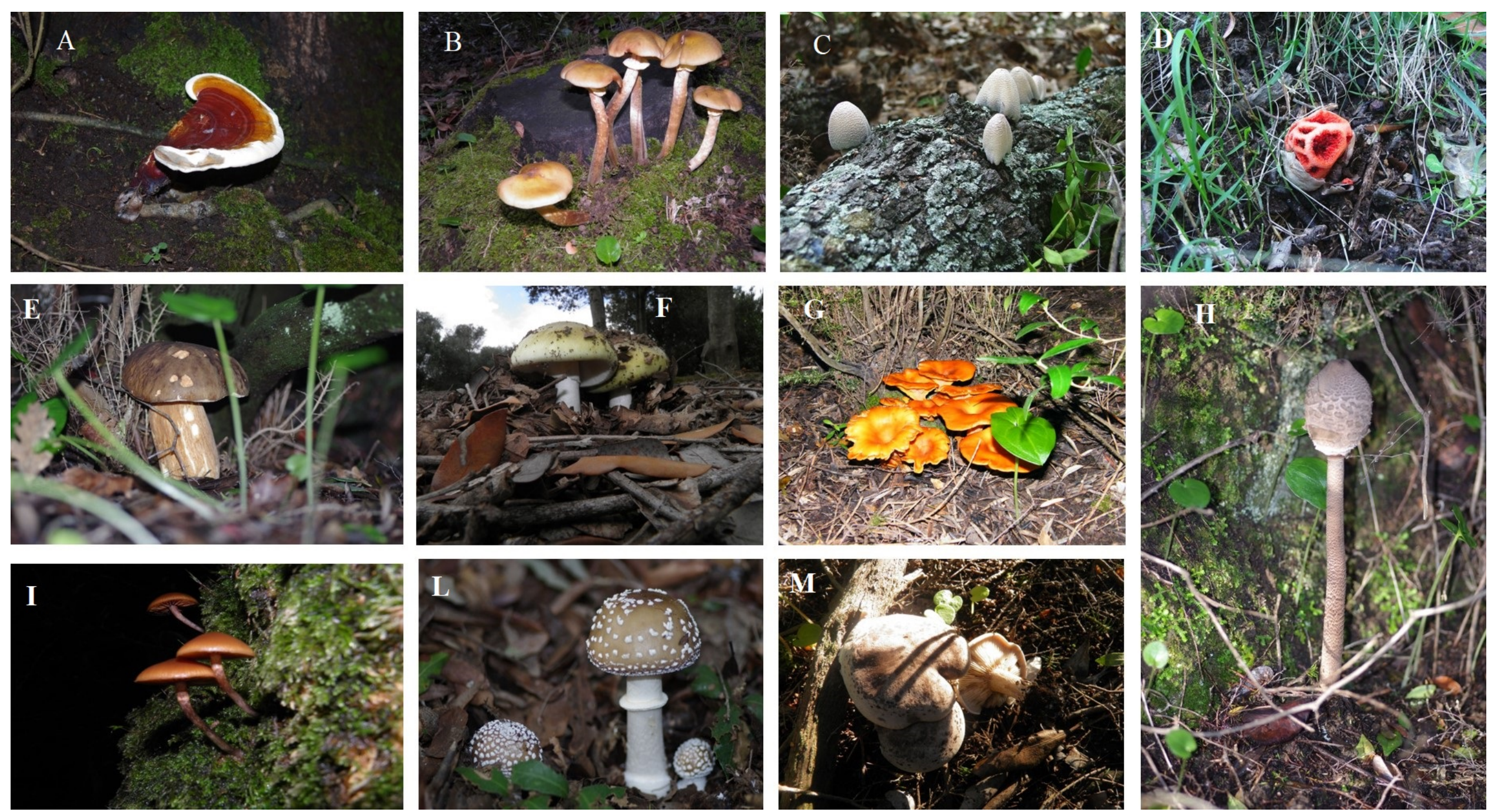

Fig. 3 - An example of the most representative species of macrofungi present on the island. A Ganoderma lucidum. B Armillaria mellea. C Coprinus sp. D Clathrus ruber. E Boletus aereus. F Amanita phalloides. G Omphalotus olearius. H Macrolepiota procera. I Galerina marginata. L Amanita pantherina. M Lepista panaeolus. 


\section{Acknowledgements}

We deeply thank Mr. Raffaele Capano for his help in some taxonomic determinations, Dr. Raffaele Panzuto for his help in the field, Prof. Chiara Maria Motta for his advice and suggestions, the head teacher Joan Tufarelli for the support of correction of the English script.

\section{References}

Aiello G., Barra D., De Pippo T., Donadio C., Petrosino C. 2007 - Geomorphological evolution of Phlegrean volcanic islands near Naples, southern Italy. Zeitschrift für Geomorphologie, N. F. 51(2): 165-190.

Caputo G. 1964 - Frammenti di querceto a roverella e di macchia mediterranea a Vivara (isole Flegree). Giornale Bot. Ital., 71: 326-330.

Cavaliere V., D’Antonio C., Zeccolella D.. 2012 - Ripresa dell'attività di inanellamento sull'isola di Vivara (NA). Poster, XI Convegno Nazionale degli Inanellatori Italiani, Gaeta (LT), February 24-26th, 2012.

De Astis G., Pappalardo L., Piochi M. 2004 - Procida volcanic history: new insights into the evolution of the Phlegraean Volcanic District (Campania region, Italy). Bulletin of Volcanology, 66: 622-641.

Consiglio G, Papetti C. 2001 - Atlante fotografico dei funghi d'Italia. Vol. 1, Edizione AMB, pp. 640.

Consiglio G. Papetti C. 2009 - Atlante fotografico dei funghi d'Italia. Vol. 3, Edizione AMB, pp. 804.

Consiglio G, Papetti C, Simonini G. 2001 - Atlante fotografico dei funghi d'Italia. Vol 2, Edizione AMB, pp. 728.

Courtecuisse R, Duhem B. 2013 - Champignons de France et d’Europe. Delachaux et niestlé, pp. 544.

Köppen W. 1936 - Das geographische System der Klimate. In Handbuch der Klimatologie, vol. 1, Berlino, Borntraeger, pp. 44.

Lancillotto L. 2014 - Indagine sulla chirotterofauna: check-list aggiornata delle specie presenti e aree d'interesse. Pp. 88-98, in "Riserva Naturale Statale Isola di Vivara Procida. Attività di riqualificazione ambientale. Report delle attività svolte. Anno 2013-2014”. Università degli Studi di Napoli, Dipartimento di Biologia, Dipartimento di Medicina veterinaria e Produzioni animali, 159 pp., 7 appendices (unpublished).

Nappi A., Cipolla R. M. , Gabriele R., Masseti M., Corti C., Arcidiacono G. 2007 - Anfibi, Rettili e Mammiferi delle isole del Golfo di Napoli: check-list commentata. Studi Trent. Sc. Nat., Acta Biologica, 83: 93-97.

Mazza R. 2010 - I funghi. Guida al riconoscimento di oltre 400 specie. Fabbri Editore, Milano, pp. 514.

Roca E., Capano L., Marziano F. 2007 - I funghi della Campania - Regione Campania, Assessorato Agricoltura, pp. 321.

Santangelo A., Scotto di Cesare M., De Luca G., Genovese M. 2014 - Monitoraggio delle popolazioni vegetali. Pp. 13-42, appendices 2.1, 2.2, 2.3, in "Riserva Naturale Statale Isola di Vivara Procida. Attività di riqualificazione ambientale. Report delle attività svolte. Anno 2013-2014”. Università degli Studi di Napoli, Dipartimento di Biologia, Dipartimento di Medicina veterinaria e Produzioni animali, 159 pp., 7 appendices (unpublished).

Scotto di Cesare M. 1999 - Vivara: flora e vegetazione. - M. D'Auria Editore, Napoli, 99 pp.

Scotto di Cesare M. 2009 - Flora fotografica di Vivara. - M. D'Auria Editore, Napoli, 269 pp.

Violante U., Roca E., Soriente S., Pizzolongo F. 1999 - Flora micologica campana (Italy) 7. I macromiceti dell’isola vulcanica di Vivara. Mic. Ital. 1999, 2, 9-19. 